\title{
Crisis in our hospital kitchens: ancillary staffing levels during an outbreak of food poisoning in a long stay hospital
}

\author{
Allyson M Pollock, Paula M Whitty
}

\begin{abstract}
An investigation into an outbreak of food poisoning caused by Clostridium perfringens showed evidence of poor food handling by catering staff. The reasons behind this were explored by interviewing catering staff, analysing shifts and rotas, and looking at staff vacancies. Morale was low because of staff shortages resulting from a long term recruitment problem. In consequence staff were working double shifts and often for weeks on end without a day off. The reasons for the recruitment problem included the difficulty of recruiting semiskilled labour from a middle class area, low wages, lack of management support, and the poor image of the hospital as a place of work. Similar factors affect the recruitment and retention of ancillary staff nationally. The NHS has a poor record as an employer of ancillary staff, paying lower wages than other organisations for equivalent posts. Competitive tendering has further worsened the position of ancillary staff, with the result that good quality of care and service has often not been achieved.

The NHS Review, with its emphasis on quality of care, makes no mention of ancillary staff. Yet high standards of ancillary provision are essential if further outbreaks of food poisoning in hospitals are to be prevented.
\end{abstract}

\section{Introduction}

An outbreak of diarrhoea occurred at a 637 bed psychiatric hospital in south east England on 11-14 June 1989. Fifty elderly residents were affected and two died. The source of the outbreak was identified. At the inquest the coroner and the press concentrated on the state of the kitchens, as outlined in the environmental health officer's report. During the course of the inquiry, however, several other problems came to light, including lapses in medical care but, above all, underlying difficulties within the catering department.

The organism causing the outbreak was identified as Clostridium perfringens type A. The source was established epidemiologically, by food questionnaire, as a minced beef meal served at lunchtime on 11 June. The

Newham Health Authority, London $\mathrm{E} 13 \mathrm{0DZ}$

Allyson M Pollock, MB, senior registrar in public health medicine

Tower Hamlets Health Authority, London EC1 Paula M Whitty, MB, registrar in public health medicine

Correspondence to: Dr Pollock.

Br.Med F 1990;300:383-5 outbreak was confined to patients in only four of the 16

TABLE I-Complement of catering staff on weekend of 10-11 Fune 1989 when outbreak of food poisoning occurred

\begin{tabular}{lccccc}
\hline & \multicolumn{2}{c}{ Saturday } & & \multicolumn{2}{c}{ Sunday } \\
\cline { 2 - 4 } Staff on duty & Recommended & Actual & & Recommended & Actual \\
\hline Head cook or deputy & 1 & 0 & 1 & 0 \\
Cooks & 4 & 2 & 4 & 2 \\
Assistant cooks & 1 & 2 & 1 & 2 \\
Kitchen porters & 3 & 2 & 2 & 2 \\
\hline Total & 9 & 6 & 8 & 6
\end{tabular}

wards that had received the meal, and this was thought to be related to division of the minced beef at a late stage in food preparation. The case fatality rate of $4 \cdot 1 \%$ was high; the expected case fatality rate based on figures for England and Wales over 1969-80 was $0.07 \%$. The necroscopic findings showed that the two patients who died had evidence of longstanding faecal impaction. Details of the full inquiry, including a casecontrol study, are available from the authors. We describe here the investigation into the staffing and morale of the catering department.

\section{Investigation}

The epidemiological inquiry included interviewing the cooks on duty over the weekend of the outbreak. Questions also covered working conditions and job satisfaction. Formal interviews were conducted with the catering manager and the hotel services manager, who were asked to provide full details of the staffing levels, vacancies, and duty rotas, including the shift arrangements for the weekend of 10-11 June 1989.

\section{Findings}

INTERVIEWS

Both duty cooks reported considerable dissatisfaction as a consequence of long term staff shortages. Interviews with the catering manager and the hotel services manager confirmed that there were vacancies in all catering grades. They thought that this severe recruitment problem was due to four factors: the difficulty of recruiting semiskilled labour from a predominantly middle class area; notoriously low paid jobs; the poor image of many psychiatric hospitals as employers; and, lastly, the personnel department's lengthy delays in responding to requests for advertisements.

Temporary promotion of cooks to more senior grades had been unsuccessful and, in any case, had resulted in vacant posts at a lower level.

\section{STAFFING}

Weekend staffing levels 10-11 Fune 1989-Table I shows that on this weekend there was a shortfall of a third of the full complement of staff on Saturday 10 June and of a quarter on Sunday 11 June. There were no supervisory cooks on duty over the weekend, and the complement of cooks was halved.

Long term staff vacancies are shown in table II: there was $45 \%$ total under-recruitment, with three assistant cooks "acting up" as cooks with no extra training. Unskilled jobs were vacant for the longest time, with obvious implications for cleaning and maintenance. The unfilled posts accounted for a total of 48 months, equivalent to four years of person time lost over the previous 16 months.

Staffing duty rotas 1 April-16 fune 1989-The 
catering department's duty rota for 1 April to 16 June 1989 is shown in table III. Staff were working repeated double shifts (shifts lasted eight and a half hours) and prolonged periods without a day off. One member of staff (No 2) worked for 35 consecutive days. Remarkably, only one member of staff (No 4) had a high sickness rate. This 24 days of sick leave during the total period had the effect of imposing additional workloads on those covering the shifts.

\section{Discussion}

The recruitment and supervision of catering staff became a key issue in the investigation of this outbreak. Staff were under pressure because of continuing underrecruitment and had to compensate for the lack of staff by working double shifts and often several weeks without a day off. The interviews with catering staff suggested that this crisis way of working culminated in the events which resulted in the outbreak. These shortages of ancillary staff were due to a combination of factors, including the local labour supply; poor wages and terms and conditions of service; insufficient recognition from senior management and health authority members of the extent of the recruitment problem; and lack of cooperation from the personnel department.

Whatever the local reasons for the low staffing levels in this case, we suspect that many other hospitals are operating at similar crisis levels. Understaffing and inadequate supervision have been implicated in previous outbreaks of food poisoning in hospitals, most notably at Stanley Royd.' The report on the Stanley Royd outbreak highlighted the importance of adequate supervision, monitoring, good management, and support of staff.

Moreover, there are persistent and disturbing reports of falling standards in ancillary services generally. ${ }^{2}$ These appear to be associated not simply with staff shortages but with reduced staffing levels that have coincided with the introduction of competitive tendering since 1983 .

\section{EFFECT OF COMPETITIVE TENDERING}

Current government thinking is that market forces will realise the ultimate aim of improving quality of service. $^{3}$ The experience of competitive tendering shows, however, that this has rarely been achieved. Instead, competitive tendering has been introduced at the expense of service provision, the patient, and the employee, with grave implications for quality.

Government guidelines stipulate that contracts must be awarded to the group submitting the lowest tender except in "exceptional" circumstances. ${ }^{2}$ District health authorities have been inhibited from stipulating quality of service in the contracts as they were debarred from asking contractors to specify performance rates and from vetting their own contract firms. ${ }^{2}$ In addition authorities have not been able to suspend outside contractors without first seeking ministerial consent, which has resulted in lengthy bureaucratic delays.

Currently there are two dominant private cleaning companies supplying the NHS: BET and Hawley, both multinational companies. They now account for nearly $45 \%$ of contracts within London and $25 \%$ of contracts outside London. A report in May 1987 by the Joint NHS Privatisation Unit revealed that during September 1983 to May 1987 these two firms had a failure rate of $25-27 \% .^{2}$ Such privatisation has had enormous implications for patient care.

As an example, Barking Hospital, the neighbouring acute hospital to the psychiatric hospital reported here, has already suffered from the introduction of tendered cleaning services. In 1984 when the contract was renewed with Crothals (Hawley group) it was on the basis of a reduction in cost of $41 \%$, and cleaning hours
TABLE II - Long term staff vacancies in catering department

\begin{tabular}{|c|c|c|c|}
\hline Staff title & $\begin{array}{c}\text { Full } \\
\text { complement }\end{array}$ & Vacancies & $\begin{array}{l}\text { Length of } \\
\text { vacancy } \\
\text { (months) }\end{array}$ \\
\hline Catering manager ${ }^{\star}$ & 1 & 0 & \\
\hline Head cook ${ }^{\star}$ & 1 & 1 & 3 \\
\hline Deputy head cook & 1 & 1 & 2 \\
\hline Cooks & 7 & 4 & $3 \times 6$ months \\
\hline Assistant cooks & 4 & 1 & 3 \\
\hline Butcher/store person & 1 & 1 & 9 \\
\hline Kitchen porters & 4 & 1 & 16 \\
\hline Domestics & (1) & (1) & $\begin{array}{l}\text { (9 months' } \\
\text { sickness } \\
\text { absence) }\end{array}$ \\
\hline Total & 20 & $9(45 \%)$ & $\begin{array}{c}48 \text { months } \\
(+9 \\
\text { for sickness })\end{array}$ \\
\hline
\end{tabular}

*Under-recruitment among senior grades $=2 / 3$.

TABLE III-Catering department duty rota 1 April-16 June 1989 for four staff

\begin{tabular}{lllc}
\hline & April & May & 1-16 June \\
\hline $\begin{array}{l}\text { Average No of hours per week } \\
1\end{array}$ & 40 & 34 & $42 \cdot 5$ \\
2 & $67 \cdot 5$ & 61 & 52 \\
3 & $51 \cdot 5$ & $55 \cdot 25$ & 58 \\
4 & $55 \cdot 5$ & 51 & 42 \\
Maximum No of consecutive & & & \\
days worked & 5 & 4 & 5 \\
1 & 21 & 35 & 7 \\
2 & 14 & 21 & 14 \\
3 & 20 & 13 & 5 \\
4 & & & \\
Total No of sick days & 8 & 16 & 0 \\
1 & 0 & 0 & 0 \\
2 & 0 & 0 & 0 \\
3 & 0 & 0 & 0 \\
4 & &
\end{tabular}

were cut by $40 \%$ from 2189 to 1313 hours a week. This had a profoundly damaging effect on both staff morale and cleaning standards.

When ancillary services in Cambridge were subcontracted to Office Cleaning Services hours of cleaning were cut by half with consequent deterioration in standards of cleanliness. ${ }^{+}$Medical staff fought hard on behalf of ancillary staff and against falling standards, but even the protest resignation of a consultant paediatrician was to no avail.

\section{ANCILLARY STAFF AND THE NHS REVIEW}

It remains to be seen whether quality will have a higher profile in the light of the NHS review, but it is striking that neither the white paper nor the working papers on self governing hospitals even mentions ancillary workers. ${ }^{6}$ Two of the main issues in the debate on self governing hospitals concern those hospitals who will find it more difficult to compete in the labour market and the emergence of differential pay rates for equivalent posts. So far, however, anxieties have been expressed largely on behalf of professional staff, with ancillary staff escaping specific mention.

Ancillary staff comprise about $15 \%$ of the NHS workforce. Their wages lag significantly behind those of equivalent posts in other organisations (see box). ${ }^{8}$ Low wages are to some extent due to patchy union representation among ancillary staff (particularly women) possibly due to a widely held view that NHS unions are "militant" organisations. "Women account for nearly $75 \%$ of ancillary staff, but only 1 in 10 of them are members of a union. ${ }^{+}$

Competitive tendering has further compromised union powers. The Whitley Council framework for negotiating rates of pay is being eroded. Although "in house" tenders are obliged to respect the Whitley rules, outside contractors are under no such restrictions, which makes it increasingly hard for in house tenders to compete effectively. These factors, together with the abolition of legislative controls on minimum 
wages, have conspired to produce a downward pressure on wages in both in house and external tenders.

Since staff wages account for $90 \%$ of the cost of ancillary services, various methods have been used to keep costs down. These include reducing staff bonuses, holiday pavments, and sick leave entitlements and cutting the number of hours worked by some employees to below 16 hours a week, thus avoiding payment of National Insurance contributions. ${ }^{+\star}$ The Department of Health and Social Security thwarted attempts by health authorities to safeguard ancillary workers' interests and wages by preventing them specifying the terms and conditions of service that private contractors should provide for staff working under NHS contracts.

Under these conditions, is it any surprise that the NHS has such a high turnover of ancillary staff and loses nearly half its workforce every year ${ }^{+}$In fact catering workers have fared marginally better than domestic staff because in house tenders for catering services have more often been successful than those for domestic services.

How will ancillary workers fare in the light of the NHS review? They wield little power and lack the voice of the professions. Union representation has at least guaranteed minimum rights, but the combined deregulation of national pay scales and the proposed removal of union representatives from health authorities will probably mean greater exploitation. This may result ultimately in a climate of discontent, even lower morale, and fragmentation of health care."

The experience of ancillary workers has implications for all staff within the NHS. Will the rights of staff to reasonable terms and conditions of service be maintained? Will quality be made subservient to the goal of cost reduction and income generation? Will quality of care suffer? What guarantees do we have as we prepare to enter the market place that provider and consumer will both benefit from the caring institution we know as the NHS?
NHS and private sector pay scales for ancillary workers (weekly gross pay for 38-39 hours)

NHS canteen assistant

Asda Stores, canteen worker

92.85

96.16

Gateway Ltd, canteen worker

109.80

British Sugar, canteen worker

130.38

NHS cook

105.65

107.40

138.32

115.63

Tesco Stores, cook

Tucker Fastners, cook

141.13

\section{NHS cleaner}

92.83

96.76

98.44

Co-op Wholesale Society, cleaner

98.44
101.45

125.00

Gateway Ltd, cleaner

92.83

96.76

99.09

132.81

Co-op Wholesale Society, porter

British Sugar, porter

Source: Income Data Services Pay Directory, September 1989.

1 Department of Health and Social Security. Report of the committee of inquiry into an outbreak of food poisoning at Stanley Royd Hospital, January 1986. London: DHSS, 1986

2 Newbiggin R, Lister J. Private health care: the record of privale companies in NHS support services. London: Association of London Health Authorities, 1988.

3 Dyson R. Radical change of policy on NHS pay. Br Med 7 1989;298:654-5.

4 Coyle A. "Dirty Business"-women's work and trade union organisation in contract cleaning. Birmingham, West Midlands Low Pay Unit, 1986.

Smith T. Conversations with consultant paediatricians. Br Med f 1988;296:

6 Secretaries for Health, Wales, Northern Ireland, and Scotland. Working for patients. London: HMSO, 1989. (Cmnd 555.)

pattents. London: HMSO, 1989. (Cmnd 555.) $1989 \cdot 298 \cdot 819$

8 Rise C. Cutting down on care: the experience of competitive tenderng in Worcester Roval Infirmarv. Birmingham: West Midlands Low Pay Unit, 1987. 9 Salvage J. The importance of hospital domestics. Br Med f 1989;298:5-6.

Accepted 28 November 1989)
A woman in her 50s has had surgery for carcinoma of the breast. She had been receiving oestrogen replacement treatment for six months before the operation and wants to continue with it. Must she stop taking it, and if not can she take tamoxifen as well?

The long established view that the use of hormone replacement treatment is contraindicated in patients with primary breast cancer because oestrogen stimulates breast tissue has recently been modified. Epidemiological studies have confirmed that such treatment does not increase the incidence of breast cancer.' If this patient is to continue with the treatment it must be a combination of oestrogen with progestogen. The question implies that she was receiving oestrogen replacement alone, which might well have been prescribed if she had had a hysterectomy. Progestogen is added to oestrogen in standard hormone replacement treatment to counteract its effect on the endometrium, which if unopposed by progestogen leads to endometrial hyperplasia or cancer. Progestogen has the same effect on breast tissue, counteracting the mitotic action of oestrogen by diverting the cells from proliferation to differentiation.

It is therefore considered safe to continue this patient's low dose combination hormone replacement treatment after breast surgery for a limited period of six months to a year provided that her menopausal symptoms for which the treatment was prescribed are sufficiently severe to justify treatment. Hormone replacement treatment is prescribed not only to alleviate menopausal symptoms but to protect against osteoporosis and cardiovascular disease long term. The question arises, therefore, whether long term combination treatment over a period of 10 years is advisable.

I would advise against prescribing long term combination hormone replacement treatment in patients who were found to have lymph node disease and oestrogen receptors at the time of the breast surgery. I would recommend long term combination treatment with careful follow up for patients without node disease or oestrogen receptors. There is some evidence that long term combination treatment might be beneficial in patients with advanced breast cancer. ${ }^{3}$ This is presumably due to the progestogen component, which can be given alone as Provera. Tamoxifen ( $20 \mathrm{mg}$ daily) is indicated whether the patient does or does not have node disease or oestrogen receptors. It may be prescribed together with combination hormone replacement treatment.-D J REID, consultan surgeon, Brighton

1 Consensus Development Conference. Prophylaxis and treatment of osteoporosis. Br Med 7 1987;295:914-5.

2 Stoll BA, Parbhoo S. Treatment of menopausal symptoms in breast cancer patients. Lancet 1988;i:1278-9.

3 Gompel A, Malet C, Spritzer P, et al. Progestin effect on cell proliferation and 17 B-hydrox steroid dehydrogenase activity in normal human breast cells in culture. 7 Clin Endocrinol Metab 1986:63:1174-80.

Are mercury vapour lamps hazardous to eyesight?

There is little evidence that mercury vapour lamps in themselves can cause damage to the eye. The bluish white light that they produce provides good visibility and prevents traffic accidents. The hazard that they may pose to human eyes and skin has caused the Food and Drug Administration in the United States to establish new protective standards. The danger is related to breakage of an outer glass shield, allowing the inner tube containing the mercury gas to irradiate the eyes with ultraviolet light. Eye injuries may occur to someone standing about $9 \mathrm{~m}$ from the broken lamp. Injuries have been recorded in association with broken mercury vapour lamps, and so in the United States new standards have been set up designed to shut off automatically the lamp when the outer globe breaks. It is clear, however, that properly shielded mercury vapour lamps do not cause any damage to the eyes. Where ultraviolet burns have happened to the cornea, although painful at the time, they inevitably resolve without any long term consequences. D L EASTY, professor of ophthalmologv, Bristol 